Nevada

Environmental

Restoration

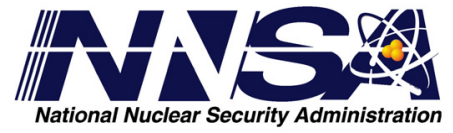

Project

\title{
Addendum 2 to the Closure Report for Corrective Action Unit 358: Areas 18, 19, 20 Cellars/Mud Pits, Nevada Test Site, Nevada
}

Controlled Copy No::

Revision No.: 0

May 2009

Approved for public release; further dissemination unlimited.

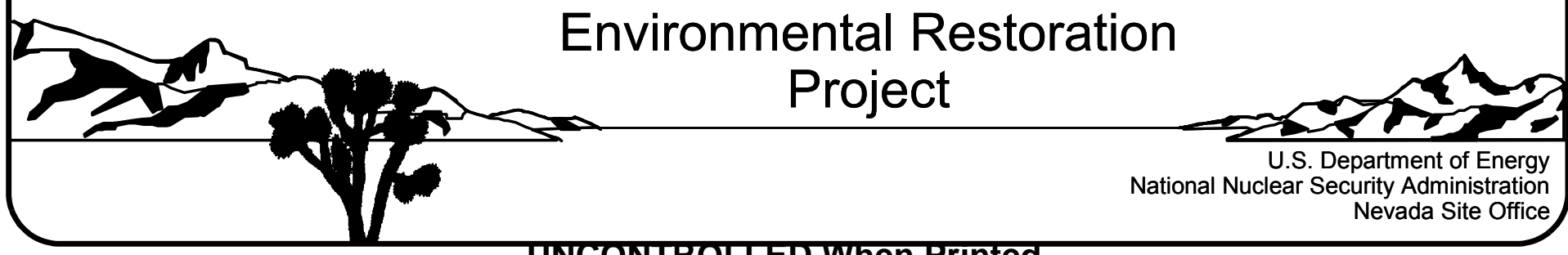


Available for public sale, in paper, from:

U.S. Department of Commerce

National Technical Information Service

5285 Port Royal Road

Springfield, VA 22161

Phone: 800.553 .6847

Fax: 703.605.6900

Email: orders@ntis.gov

Online ordering: http://www.ntis.gov/ordering.htm

Available electronically at $\underline{h t p: / / w w w . o s t i . g o v / b r i d g e ~}$

Available for a processing fee to U.S. Department of Energy and its contractors, in paper, from:

U.S. Department of Energy

Office of Scientific and Technical Information

P.O. Box 62

Oak Ridge, TN 37831-0062

Phone: 865.576 .8401

Fax: 865.576.5728

Email: reports@adonis.osti.gov

Reference herein to any specific commercial product, process, or service by trade name, trademark, manufacturer, or otherwise, does not necessarily constitute or imply its endorsement, recommendation, or favoring by the United States Government or any agency thereof or its contractors or subcontractors. 


\title{
ADDENDUM 2 TO THE CLOSURE REPORT FOR CORRECTIVE ACTION UNIT 358: AREAS 18, 19, 20 CELLARS/MUD PITS, NEVADA TEST SITE, NEVADA
}

\author{
U.S. Department of Energy \\ National Nuclear Security Administration \\ Nevada Site Office \\ Las Vegas, Nevada
}

Controlled Copy No.:

Revision No.: 0

May 2009

Approved for public release; further dissemination unlimited.

Reviewed and determined to be UNCLASSIFIED.
Derivative Classifier: Joseph Johnston, SNJV Classification Officer
Signature: $\frac{1 \mathrm{~s} / \text { Joseph Johnston }}{\text { (Nersonal identifier and position title) }}$
Date: $5 / 11 / 2009$




\section{Addendum 2 to the Closure Report for Removal of the Use Restriction}

This document constitutes an addendum to the Closure Report for Corrective Action Unit 358: Areas 18, 19, 20 Cellars/Mud Pits, Nevada Test Site, Nevada, January 2004 as described in the document Supplemental Investigation Report for FFACO Use Restrictions, Nevada Test Site, Nevada (SIR) dated November 2008. The SIR document was approved by NDEP on December 5, 2008. The approval of the SIR document constituted approval of each of the recommended UR removals. In conformance with the SIR document, this addendum consists of:

- This page that refers the reader to the SIR document for additional information

- The cover, title, and signature pages of the SIR document

- The NDEP approval letter

- The corresponding section of the SIR document

This addendum provides the documentation justifying the cancellation of the UR for CAS 19-09-05, Mud Pit. This UR was established as part of a Federal Facility Agreement and Consent Order (FFACO) corrective action and is based on the presence of contaminants at concentrations greater than the action levels established at the time of the initial investigation (FFACO, 1996).

Since this UR was established, practices and procedures relating to the implementation of risk-based corrective actions (RBCA) have changed. Therefore, this UR was reevaluated against the current RBCA criteria as defined in the Industrial Sites Project Establishment of Final Action Levels (NNSA/NSO, 2006). This re-evaluation consisted of comparing the original data (used to define the need for the UR) to risk-based final action levels (FALs) developed using the current Industrial Sites RBCA process.

The re-evaluation resulted in a recommendation to remove the UR because contamination is not present at the site above the risk-based FALs. Requirements for inspecting and maintaining this UR will be canceled, and the postings and signage at this site will be removed. Fencing and posting may be present at this site that are unrelated to the FFACO UR such as for radiological control purposes as required by the $N V / Y M P$ Radiological Control Manual (NNSA/NSO, 2004). This modification will not affect or modify any non-FFACO requirements for fencing, posting, or monitoring at this site.

\section{References}

FFACO, see Federal Facility Agreement and Consent Order.

Federal Facility Agreement and Consent Order. 1996 (as amended). Agreed to by the State of Nevada, U.S. Department of Energy, and U.S. Department of Defense.

NNSA/NSO, see U.S. Department of Energy, National Nuclear Security Administration Nevada Site Office. 
NNSA/NV, see U.S. Department of Energy, National Nuclear Security Administration Nevada Operations Office.

U.S. Department of Energy, National Nuclear Security Administration Nevada Site Office. 2004. Closure Report for Corrective Action Unit 358: Areas 18, 19, 20 Cellars/Mud Pits, Nevada Test Site, Nevada, Rev. 0, DOE/NV--944. January. Las Vegas, NV.

U.S. Department of Energy, National Nuclear Security Administration Nevada Site Office. 2004. NV/YMP Radiological Control Manual, DOE/NV/11718--079, Rev. 5. Prepared by Bechtel Nevada. Las Vegas, NV.

U.S. Department of Energy, National Nuclear Security Administration Nevada Site Office. 2006. Industrial Sites Project Establishment of Final Action Levels, Rev. 0, DOE/NV--1107. Las Vegas, NV.

U.S. Department of Energy, National Nuclear Security Administration Nevada Site Office. 2008. Supplemental Investigation Plan for FFACO Use Restrictions, Nevada Test Site, Nevada, Rev. 0, DOE/NV--1256. Las Vegas, NV. 
Nevada

Environmental

Restoration

Project

Supplemental Investigation Report for

FFACO Use Restrictions

Nevada Test Site, Nevada

Controlled Copy No::

Revision No.: 0

November 2008

Approved for public release; further dissemination unlimited.

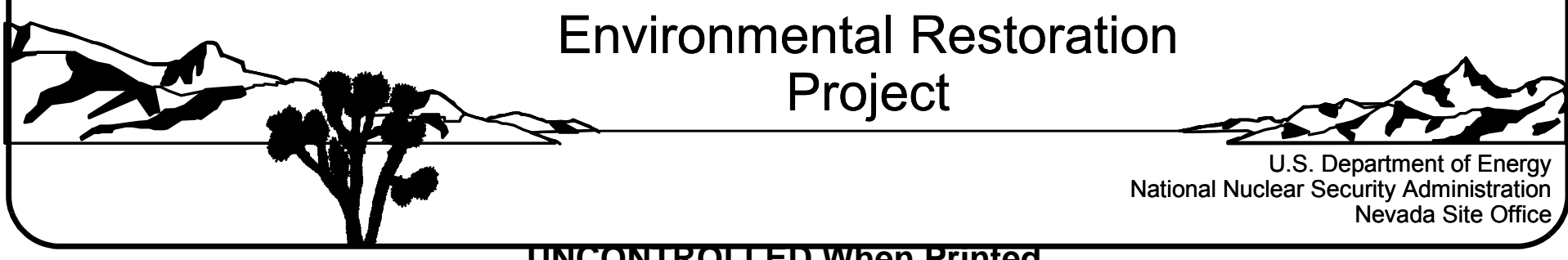




\section{SUPPLEMENTAL INVESTIGATION REPORT FOR FFACO USE RESTRICTIONS NEVADA TEST SITE, NEVADA}

U.S. Department of Energy

National Nuclear Security Administration

Nevada Site Office

Las Vegas, Nevada

Controlled Copy No.:

Revision No.: 0

Reviewed and determined to be UNCLASSIFIED.

This review does not constitute clearance for public release.

Derivative Classifier: Joseph Johnston, CO

Signature: /s/Joseph Johnston

Date: $11 / 24 / 20,08$

November 2008

Approved for public release; further dissemination unlimited. 


\section{SUPPLEMENTAL INVESTIGATION REPORT FOR FFACO USE RESTRICTIONS: NEVADA TEST SITE, NEVADA}

Approved by: /S/Kevin J. Cabble

Date: $11 / 12 / 2008$

Kevin J. Cabble

Federal Sub-Project Director

Industrial Sites Sub-Project

Approved by: /S/ Robert F. Boehlecke

Date: $11 / 12 / 2008$

Robert F. Boehlecke

Federal Project Director

Environmental Restoration Project 


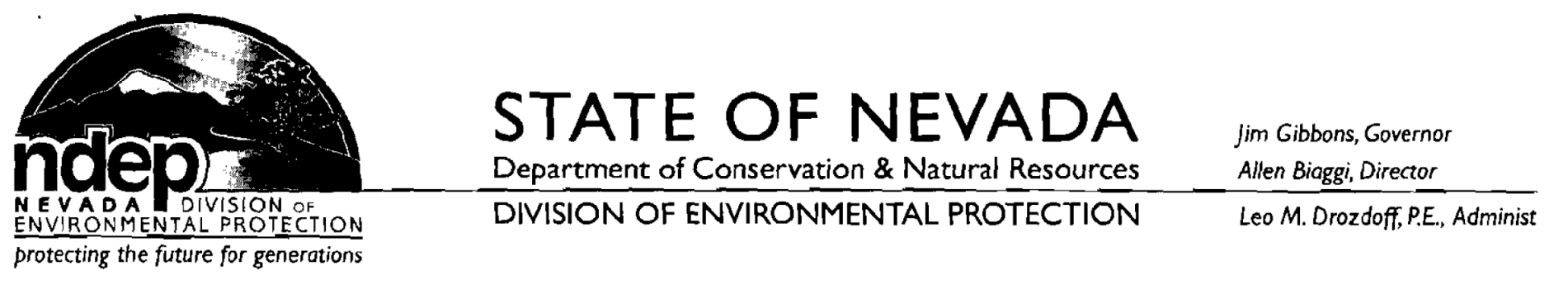

December 5, 2008

Robert F. Boehlecke

Federal Project Director

Environmental Restoration Project

National Nuclear Security Administration

Nevada Site Office

P. O. Box 98518

Las Vegas, NV 89193-8518

RE: Approval of Final Supplemental Investigation Report for FFACO Use Restrictions Nevada Test Site and Tonopah Test Range, Nevada, Revision 0, November 2008 Federal Facility Agreement and Consent Order

Dear Mr. Boehlecke:

The Nevada Division of Environmental Protection, Bureau of Federal Facilities (NDEP) staff has received and reviewed the submittal of the Final Supplemental Investigation Report for FFACO Use Restrictions, Nevada Test Site and Tonopah Test Range, Nevada, Revision 0 , November 2008. The report is hereby approved without comments pursuant to Subpart XII.8.a of the Federal Facility Agreement and Consent Order (FFACO).

Address any questions regarding this matter to either Ted Zaferatos at (702) 486-2850, ext. 234, Jeff MacDougall at (702) 486-2850, ext. 233, or me at (702) 486-2850, ext. 231.

Sincerely,

/s/Chris Andres for

T.H. Murphy

Chief

Bureau of Federal Facilities
ACTION

INFO

NSO/MGR

AMBCM

AMEM

AMNS

AMSO

AMSS

COR-RAI-

File Code 
Robert F. Boehlecke

Page 2

December 5, 2008

JJM $/ T Z$

cc: $\quad$ K. J. Cabble, ERP, NNSA/NSO, Las Vegas, NV

E.F. DiSanza, WMP, NNSA/NSO

FFACO Group, PSG, NNSA/NSO, Las Vegas, NV

Jeffrey Fraher, DTRAVCXT, Kirkland AFB, NM

W.R. Griffin, SNJV/DTRA, M/S 645, Mercury, NV

T.A. Thiele, NSTec, Las Vegas, NV

John Wong, Dennis Nicodemus, Kevin Campbell, NDEP Las Vegas, NV 
Table 4-5

Sample Results for SVOCs Detected above Minimum

Detectable Concentrations at UR 12-19-01

\begin{tabular}{||c|c|c|c||}
\hline \multirow{2}{*}{$\begin{array}{c}\text { Sample } \\
\text { Location }\end{array}$} & $\begin{array}{c}\text { Sample } \\
\text { Number }\end{array}$ & $\begin{array}{c}\text { Depth } \\
\text { (ft bgs) }\end{array}$ & Contaminants of Potential Concern (mg/kg) \\
\cline { 3 - 4 } & & Bis(2-Ethylhexyl)Phthalate \\
\hline \multicolumn{3}{|c|}{ Final Action Levels ${ }^{\mathrm{a}}$} & $\mathbf{1 2 0}$ \\
\hline \hline D02 & 339D002 & $0.0-0.5$ & 0.91 \\
\hline
\end{tabular}

aBased on U.S. Environmental Protection Agency, Regional Screening Levels for Chemical Contaminants at Superfund Sites (EPA, 2008a).

bgs $=$ Below ground surface

$\mathrm{ft}=$ Foot

$\mathrm{mg} / \mathrm{kg}=$ Milligrams per kilogram

\subsection{CAU 358, CAS 19-09-05 - Mud Pit}

\subsubsection{CAS Description}

Corrective Action Site 19-09-05 consists of a mud pit located in Area 19. The mud pit measures 97 by $81 \mathrm{ft}$, with a $1-\mathrm{ft}$ thick accumulation of dry drilling mud within its boundaries. Because diesel fuel was commonly used as a drilling lubricant, elevated levels of TPH were detected at the site. The site was subjected to corrective actions that included the implementation of a UR for TPH contamination (NNSA/NSO, 2003).

\subsubsection{Current Use Restriction Description}

A UR is in place at the site due to TPH contamination. The UR, as recorded in the FFACO, states the future use of land related to this CAU, as described by surveyed location, is restricted from DOE or U.S. Air Force activity that may alter or modify the containment control, as identified by the state and in the CR or other CAU documentation, unless appropriate concurrence is obtained in advance.

T-posts mark the corner of the active UR 19-09-05. There are no monitoring requirements associated with the UR (NNSA/NSO, 2004).

\subsubsection{Basis for Current Use Restriction}

Samples collected at CAS 19-09-05 were analyzed for VOCs, SVOCs, TPH, PCBs, total Resource Conservation and Recovery Act metals, and gamma spectroscopy. Based on the results, TPH was the 
only contaminant present above action levels. Concentrations of TPH exceeded the action level of $100 \mathrm{mg} / \mathrm{kg}$ in all four samples; therefore, a UR was implemented. Table 4-6 contains analytical results for soil samples used to establish UR 19-09-05 (NNSA/NSO, 2004). Although VOC and SVOC concentrations were reported below action levels, the action levels and analytical results are not present in the initial investigation documentation. Therefore, this site was included in the supplemental investigation.

Table 4-6

Sample Results for the Basis of UR 19-09-05

\begin{tabular}{||c|c|c|c|}
\hline \multirow{2}{*}{$\begin{array}{c}\text { Sample } \\
\text { Identification }\end{array}$} & $\begin{array}{c}\text { Depth } \\
\text { (ft bgs) }\end{array}$ & $\begin{array}{c}\text { TPH Diesel } \\
(\mathbf{m g} / \mathbf{k g})\end{array}$ & $\begin{array}{c}\text { TPH Oil } \\
(\mathbf{m g} / \mathbf{k g})\end{array}$ \\
\cline { 3 - 4 } & $\begin{array}{c}\text { Action Level } \\
\mathbf{1 0 0} \mathbf{~ m g / k g}\end{array}$ & $\begin{array}{c}\text { Action Level } \\
\mathbf{1 0 0} \mathbf{~ m g / k g}\end{array}$ \\
\hline \hline $190905-0-1 \mathrm{MP}$ & Surface & $\mathbf{1 3 8}$ & $\mathbf{9 7 0}$ \\
\hline $190905-6-1 \mathrm{MP}$ & 0.5 & 17 & $\mathbf{1 5 0}$ \\
\hline $190905-0-2 \mathrm{MP}$ & Surface & 15 & $\mathbf{1 7 0}$ \\
\hline $190905-1-2 \mathrm{MP}$ & 1.0 & 22 & $\mathbf{1 7 0}$ \\
\hline
\end{tabular}

Note: Bold text indicates value exceeding the action level.

bgs $=$ Below ground surface

$\mathrm{ft}=$ Foot

$\mathrm{mg} / \mathrm{kg}=$ Milligrams per kilogram

$\mathrm{TPH}=$ Total petroleum hydrocarbons

\subsubsection{Basis for Use Restriction Modification}

Two new environmental samples were collected at CAS 19-09-05 according to the sampling plan (NNSA/NSO, 2008) and analyzed for VOCs and SVOCs in which the hazardous constituents of TPH are reported. Table 4-7 presents the VOC results that were detected above the MDCs. None of the SVOCs were detected above MDCs.

The analytical results were evaluated using the RBCA process (NNSA/NSO, 2006) in which the individual results of contaminants (detected above the MDCs) were compared to the FALs. None of the hazardous constituents of TPH were identified above their respective FALs; therefore, there are no COCs present at this site. 
Table 4-7

Sample Results for VOCs Detected above Minimum

Detectable Concentrations at UR 19-09-05

\begin{tabular}{|c|c|c|c|c|c|}
\hline \multirow[b]{2}{*}{ 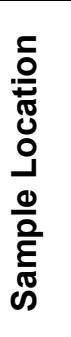 } & \multirow[b]{2}{*}{ 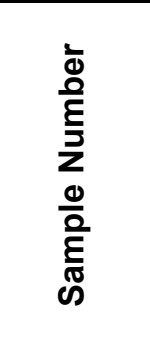 } & \multirow[b]{2}{*}{ 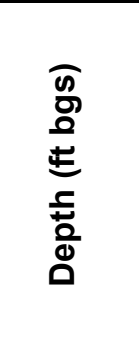 } & \multicolumn{3}{|c|}{ Contaminants of Potential Concern $(\mathrm{mg} / \mathrm{kg})$} \\
\hline & & & 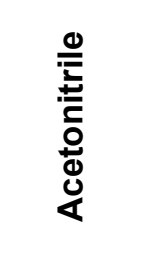 & 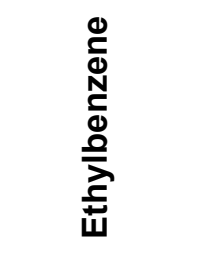 & 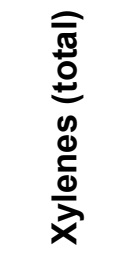 \\
\hline \multicolumn{3}{|c|}{ Final Action Levels $^{a}$} & 1,800 & 400 & 420 \\
\hline G01 & $358 G 001$ & $0.0-0.5$ & $0.015(\mathrm{~J})$ & $0.000388(\mathrm{~J})$ & 0.00173 \\
\hline G02 & $358 G 002$ & $0.0-0.5$ & -- & $0.000307(\mathrm{~J})$ & 0.0017 \\
\hline
\end{tabular}

${ }^{a} B a s e d$ on U.S. Environmental Protection Agency, Regional Screening Levels for Chemical Contaminants at Superfund Sites (EPA, 2008a).

bgs $=$ Below ground surface $\mathrm{ft}=$ Foot

$\mathrm{mg} / \mathrm{kg}=$ Milligrams per kilogram
$\mathrm{J}=$ Estimated value

-- = Not detected above minimum detectable concentrations.

\subsubsection{Recommended Modification}

Remove the FFACO UR, signage, and associated inspection and maintenance requirements from this site.

\subsection{CAU 403, CAS 03-02-004-0360 - Underground Storage Tanks}

\subsubsection{CAS Description}

Corrective Action Site 03-02-004-0360 consists of subsurface petroleum hydrocarbon releases from two USTs (one gasoline and one diesel) formerly located at the Second Gas Station in Area 3 of the TTR. The Second Gas Station was in use from approximately 1965 to 1980. The USTs were located approximately $36 \mathrm{ft}$ east of the Old Light Duty Shop, Building 0360. Sometime between August 8, 1982, and June 13, 1987, the two USTs and associated dispensary stations were removed. During removal of the 4000-gal diesel UST, a breach was observed below the top of the tank, and the soil surrounding the tank appeared to be visibly contaminated. There were no visible signs of contamination during removal of the gasoline tank. The site was subject to corrective actions that included the implementation of a UR for TPH contamination (DOE/NV, 1996). 


\section{References}

DOE/NV, see U.S. Department of Energy, Nevada Operations Office.

EPA, see U.S. Environmental Protection Agency.

FFACO, see Federal Facility Agreement and Consent Order.

Federal Facility Agreement and Consent Order. 1996 (as amended February 2008). Agreed to by the State of Nevada; U.S. Department of Energy, Environmental Management; U.S. Department of Defense; and U.S. Department of Energy, Legacy Management.

NNSA/NSO, see U.S. Department of Energy, National Nuclear Security Administration Nevada Site Office.

U.S. Department of Energy, National Nuclear Security Administration Nevada Site Office. 2003. Streamlined Approach for Environmental Restoration Plan for Corrective Action Unit 358: Areas 18, 19, 20 Cellars/Mud Pits, Nevada Test Site, Nevada, Rev. 1, DOE/NV--837-Rev 1. February. Las Vegas, NV.

U.S. Department of Energy, National Nuclear Security Administration Nevada Site Office. 2004. Closure Report for Corrective Action Unit 358: Areas 18, 19, 20 Cellars/Mud Pits, Nevada Test Site, Nevada, Rev. 0, DOE/NV--944. January. Las Vegas, NV.

U.S. Department of Energy, National Nuclear Security Administration Nevada Site Office. $2004 \mathrm{f}$. NV/YMP Radiological Control Manual, DOE/NV--11718-079, Rev. 5. Prepared by Bechtel Nevada. Las Vegas, NV.

U.S. Department of Energy, National Nuclear Security Administration Nevada Site Office. 2006. Industrial Sites Project Establishment of Final Action Levels, Rev. 0, DOE/NV--1107. Las Vegas, NV.

U.S. Department of Energy, National Nuclear Security Administration Nevada Site Office. 2008. Supplemental Investigation Plan for FFACO Use Restrictions, Nevada Test Site, Nevada, Rev. 0, DOE/NV--1256. Las Vegas, NV.

U.S. Department of Energy, Nevada Operations Office. 1996. Corrective Action Investigation Plan: The Second Gas Station Underground Storage Tanks, Rev. 0, DOE/NV--426. May. Las Vegas, NV.

U.S. Environmental Protection Agency. 2008a. Regional Screening Levels for Chemical Contaminants at Superfund Sites. As accessed at http://epa-prgs.ornl.gov/chemicals/index.shtml on 27 July. Prepared by EPA Office of Superfund and Oak Ridge National Laboratory. 


\section{Library Distribution List}

\section{$\underline{\text { Copies }}$}

U.S. Department of Energy

1 (Uncontrolled, electronic copy)

National Nuclear Security Administration

Nevada Site Office

Technical Library

P.O. Box 98518, M/S 505

Las Vegas, NV 89193-8518

U.S. Department of Energy

1 (Uncontrolled, electronic copy)

Office of Scientific and Technical Information

P.O. Box 62

Oak Ridge, TN 37831-0062

Southern Nevada Public Reading Facility

2 (Uncontrolled, electronic copies)

c/o Nuclear Testing Archive

P.O. Box 98521, M/S 400

Las Vegas, NV 89193-8521

Manager, Northern Nevada FFACO

1 (Uncontrolled, electronic copy)

Public Reading Facility

c/o Nevada State Library \& Archives

100 N Stewart Street

Carson City, NV 89701-4285 